\title{
Bureaucratic System in Bangladesh
}

\section{Md. Amir Hossain*}

M.Phil. Research Scholar,Department of English, Jahangirnagar University, Bangladesh.

\begin{abstract}
This study would like to examine the Bureaucratic System in Bangladesh. It aims to look at the $21^{\text {st }}$-century political situations in the light of Bureaucracy. It makes us conscious of the negative aspects of public administration. It also shows the geographical location of Bangladesh.
\end{abstract}

Keywords: Bureaucratic system; Political situations; Public administration

\section{Introduction}

The political name of Bangladesh is the People's Republic of Bangladesh. Capital of Bangladesh is Dhaka, which is the largest city. Bengali is the native language and English is the official second language. Among the ethnic groups, $97.2 \%$ are Bengali and other is $2.8 \%$. The government of Bangladesh is unitary parliamentary of democracy. Jatio Shangshad is its legislation. It got freedom from Pakistan on $26^{\text {th }}$ March 1971. 16 December is the Victory Day of the same year in Bangladesh. Total area of Bangladesh is 1,47,570 square kilometers. According to the 2012-census, population is approximately 160 million. Population density per square kilometer is about 1100 , which is one of the highest in the world. In the sauce of reality, Bangladesh is a witnessing country of the world in terms of population density. Gross Domestic Product (GDP) in PPP is estimated \$282.229 billion (2011) and per capita GDP in PPP of Bangladesh is $\$ 1,790.26$ [1]. Nominal GDP is $\$ 113.032$ billion and per capita $\$ 700.59$. In terms of HDI, Bangladesh tends to enter in the middle-income countries, which is 0.500 (2011).

\section{Bureaucratic System in Bangladesh - An Overview}

An effective public administration is the key factor for the efficient growth and development of a country. Bangladesh is such a developing country, where bureaucrats come of middle, or lower middle class. They are experienced with poverty-prone environment. They become bureaucrats after taking the competitive exams. It means that they are qualified and smart enough. Some other characteristics may be good or bad in nature. Bureaucrats are powerful in society. They try to please their politicians in power. Bureaucrats are also found to misuse their power in position to obtain their own gains including keeps and bribes. To help achieve the goal or benefit for the common people, an efficient administrative capacity is very essential. With that purpose in mind, bureaucratic institution is formed in any other countries, including Bangladesh. The effectiveness of an organization is determined by the personal quality and characteristics of the administrative individuals who are responsible to perform their duties and responsibilities [2].

Bangladesh is a country about black money. In Bangladesh, 40 lakhs people or only $2.4 \%$ people have Tax Identification Number (TIN). In reality, a less than $1 \%$ people or little more than 10 lac people pay taxes to the Government. The government does not have enough revenue for the fiscal budget. Bureaucratic officials receive a very little in member as the monthly compensation [3]. In Bangladesh, compensation for the Government Official is equal or even less than its senior clerk in private sector. Bureaucrats do not receive market wage. To meet basic need, they must depend on keeps and bribes. They commit all kinds of corruption including seed-money and speed-money corruption. Individuals pay bribes to bureaucrats as a seed-money when they start a business. Again, people pay them bribes to help move the file from table to table as a speed-money. So, bureaucratic corruption in Bangladesh has been an acute problem and an indigenous culture in the sector of public administration [4].

The goal of the administrative development is to provide essential services to its citizens. However, negative culture, poor salary, bureaucratic power, weak law-and-order and judiciary systems--these environments are not favorable for the bureaucracy to provide the proper service to the citizen. The effort to persuade civil services of the developing countries, like Bangladesh is likely to produce bureaucratic inefficiency rather than providing desired services to its citizen. It is true that political rulers of developing countries, like Bangladesh are adequately in command of political power, which aggravates the working environment of bureaucracy. Most administrative expert recommends maximizing the use of knowledge rather than building power and authority. However, bureaucrats simultaneously acquire more power and authority and misuse their power to un-provisionally obtain own gains from the common people of the country.

Bureaucracy never let local bodies strengthen in Bangladesh. It is the traditional bureaucracy to suppress and oppress the local bodies at any of capacity. We have a three-tire-system of local bodies: district board in each district, a local board in sub-division of a district called Thana and a Union committee for a group of villages. The idea is conceived to establish a network of local bodies and to train and prepare them for performing the local administration. It is the responsibility of the civil administration to provide a political education to the rural people through local bodies. However, the philosophy of strengthening local administration is not partly acceptable to civil service officials. Local government organizations are put completely under the disposal of bureaucracy as an attempt to extend. Bureaucracy in Bangladesh is historically a Pro-British culture where the government has been unable or having hard time to empower the local government adequately due to opposition from Thana Neerbahi Officer (TNOs). The TNO is supposed to act as the secretary to the Thana Parishad. Bureaucrats at the district level have long been running the Zila Parishad in the absence of an elected representative. Deputy Commissioner (DC) and

*Corresponding author: Md. Amir Hossain, M.Phil. Research Scholar,Department of English, Jahangirnagar University, Bangladesh, Tel: 8801915908306; E-mail: amir.hossain.16578@gmail.com

Received June 13, 2017; Accepted June 21, 2017; Published June 24, 2017

Citation: Hossain A (2017) Bureaucratic System in Bangladesh. Review Pub Administration Manag 5: 214. doi:10.4172/2315-7844.1000214

Copyright: (C) 2017 Hossain MA. This is an open-access article distributed under the terms of the Creative Commons Attribution License, which permits unrestricted use, distribution, and reproduction in any medium, provided the original author and source are credited. 
TNO are still the ones who have been holding the range of power of Thana and district level. They enjoy sweeping authority over the Union Parishad, which is the lowest tire of the local government system in Bangladesh. Bureaucracy and its associated culture have become a hindrance or constraint to consolidation and effective functioning of bureaucracy in Bangladesh.

In case of a conflict between bureaucrats and local government functionaries, the control of the government tends to favor the bureaucrats to retain the central control over the local government. The Government's legislation in Bangladesh lacks its effectiveness to take action against corruption due to weak law-and-order. Politicization has been a negative culture in Bangladesh. The entire bureaucracy is left an inefficient and demoralized state. Some bureaucracy takes the form of a demonstrative part of the political showmanship. It is not very easy for the political government in Bangladesh to implement its policy, goals and manifesto, because the democracy under any political party in Bangladesh is not impartial, natural and professional. It is very unusual to behold the fact that the Government behaves more with its political philosophy and the political party-in-power as if they are government themselves.

Annual Confidential Reports (ACR) is essential to consider the promotion of civil service, their fairness and integrity. ACR will have to be maintained at any cost. It is not unlikely that ACR gets politicized. Therefore, some deserving candidate does not get promotion. Rather, he can be indirectly sacked from duties in the name of Officer on Special Duties (OSD). To expedite the decision-making process, we have to have a method of breaking the multilayered bureaucracy. Unfortunately, a normal practice in Bangladesh is to keep the administration overcentralized. The method of disseminating information on public inquires and the service delivery by the government has to be improved as early as possible. Any government needs a trusted and dedicated bureaucracy to bring dynamism in the public function and in the implementation of the Government's mission and vision. In Bangladesh, importance is given on regular training and recruitment of Bangladesh Civil Service (BCS) Cadre. Bureaucracy is not working very well due to traditional culture of self-interest and corruption etc. If the bureaucracies were fair enough, our democracy would have worked very well. But due to corruption and politicization, our democrats have been playing a role of autocrats.

Bangladesh is mainly a land of the village, where seventy six (76\%) or 114 million people live in rural areas and or 36.4 million or $24 \%$ people live in urban and semi-urban cities. Our major goal and objectives would have to have a qualitative change in the life-style of the majority of people, particularly in the rural areas. So, our production, distribution and consumption of goods and services should be decentralized to achieve the target of rural benefit. Decentralization must have an administrative strategy for increasing the decision making capacity and effectiveness of the local bodies or administration. Once again, such an ideal target can be achieved through redistribution of power and resources smoothly through top-down process. In order to satisfy the demand for the people in rural Bangladesh, we need to do the following things: (a) reducing dependency of the rural people on the national government in order to meet the needs that can be addressed locally; developing self-reliance in the process; (b) mobilize and utilize local untapped resources, and (c) directly involve the local government in planning and implementation of these projects [5]. The main functions of Thana Parishad are of the following:

$>$ To prepare development plan;
To implement all the transferred activities of the government;

To coordinate and monitor all the departments entrusted to the Upazila;

$>$ To conduct, repair and maintain the feeder road;

To ensure the service of primary health, nutrition and family planning;

To take necessary steps for supplying pure drinking water to the people of the locality;

$>$ To facilitate and take necessary programs for the welfare of the people etc.

The government has adequate degree of control over the budget of Thana Parishad. Upazila Parishad lacks discipline and accountability. Thana Parishad is an extension of the central government to execute the activities at the local level. There is a lack of working relationship between centrally organized bureaucracy and Thana Parishad [6]. There is a lack of co-ordination between the Thana Chairman and the bureaucrats. Central government is dictating all about Thana through bureaucrats. On the other hand, the Thana Chairman is not satisfied with their status. Even though they are the people's representatives, government body is the supreme authority of local government. As we know, bureaucrats always serve their own interest. Bureaucratic complexity as made the local body ineffective. A meaningful decentralization has been necessary for the administrative power to achieve the overall development of Thana level.

\section{Discussion}

It is important to note that both the admirers and critics on the crucial significance of the civil service is the leery institutional determinant of the success or failure of fledging democratic state, especially in the developing world. The people are eager to see the course of the promised digital Bangladesh, or e-Governance, as proper implementation will bring the much-awaited good governance. For this, the government must take an initiative to align the bureaucracy towards e-Governance. E-Governance speeds up the government's delivery system by eliminating red-tapism. It also ensures social equity by reducing corruption and increasing transparency. So, it can be expected that many corrupted bureaucrats will try to resist proper implementation of e-Governance. No doubt, corruption is the most detrimental factor that hinders our national development. Though corrupted politicians put the country at stake, their partners are bureaucrats. At the state level, no government can get involved in corruption without the help of the bureaucrats. In the past, the nation saw that although some politicians were tried and punished for their involvement in corruption, their counterparts in the bureaucracy, in most cases, escaped [7].

The major problems in bureaucracy are cultural. Bureaucrats are assumed to be the master instead of the citizen, because the bureaucrats are given enormous power to rule the country on their behalf. In their home-country, the British installed a relatively people's friendly bureaucracy, but in their colonial countries they create oppressive bureaucracy for obvious reasons.

For the smooth running of the government, the bureaucracy must be depoliticized. Just making some politicized bureaucrats officer on special duties (OSD) will not work. OSD system is a waste of public money. The best policy should engage and motivate the bureaucrats to work for the national building activities under the close supervision 
of concerned minister [8]. The government has to be aware that it does not need any politicized bureaucrats. The government requires effective and efficient bureaucrats who objectively execute the government policy to get the desired output. Minister must maintain their supremacy over their respected bureaucrats. In other words, if a minister is honest, sincere, patriot and prudent then most corrupted and cunning bureaucrats are impossible to be derailed. In other words, ministers must have their personal integrity, honesty and commitment to the people. As a part of good governance, minister must be smart enough as a policy maker. And, the bureaucrats should act as mere executor of the policy. If the ministers opined 'yes sir', 'no sir', and 'very good sir' along the line the Prime Minister wants the democracy gets converted to autocracy.

\section{Conclusion}

Finally, we can say that to develop the country as well as the nations, the conscious citizen and the Government should come forward concertedly so that we can get a corruption free state. In this regard, dishonest bureaucrats should be punished with an iron rod. It is the duty and responsibility of all sorts of people to tackle the political crisis. Then it would be possible for us to stand upright in the global atlas with due respect and veneration.

\section{References}

1. Giasuddin AS (2002) Public administration in the three decades. Bangladesh: On the threshold of the twenty-first century. Dhaka. A.M. Chowdhury, Fakrul Alam (eds) Dhaka: Asiatic Society of Bangladesh pp. 321-354.

2. Shawkat-Ali AMM (2004) Bangladesh Civil Service: A Political administrative perspective. Dhaka University Publisher Limited.

3. Financial Express (2005) Programme to increase efficiency of bureaucrats next year, Financial Express, Dhaka.

4. Khan MM (2003) The state of governance in Bangladesh. The Round Table 370: $391-405$.

5. Rahman MM (1997) Bureaucratic response to administrative decentralization Dhaka, UPL.

6. Kamal S (2006) Fifty unpleasant essays. Towards good governance in Bangladesh. Dhaka University Publisher Limited.

7. World Bank (1996) Government that works: Reforming the Public Sector Dhaka, UPL.

8. Habib Z (1988) Recruitment and training: Bureaucratic Intervention. Bureaucratic Ascendancy: Public administration in Bangladesh: The first three decades. Habib Zafarullah, Mohammad Mohabbat Khan (Eds) Dhaka: AHDPH pp. 125-148. 